\title{
GENDER DISCRIMINATION IN AGRICULTURAL SECTOR: A STUDY ON MURSHIDABAD DISTRICT, WEST BENGAL, INDIA
}

\author{
Banti Das \\ Lecturer in Geography, Nagar College, Nagar, Murshidabad, West Bengal \\ DOI: 10.46609/IJSSER.2020.v05i08.018 URL: https://doi.org/10.46609/IJSSER.2020.v05i08.018
}

\begin{abstract}
Gender discrimination means 'male-female differences' that arise from various factors like biological, psychological and cultural norms. It is the process by which people are treated differently only for their gender at home, school or working sector. It also creates a major problem in agricultural sector especially in developing countries like India. Murshidabad district is one of the favourable agricultural regions in West Bengal. Agricultural sector offers many jobs for both male and female but difference in wages earned by them persists and it determines the male-female work participation in agriculture in this area. Many obstacles such as high illiteracy rate among women, lack of consciousness about their legal right, religious obstacles and limited access to resources like land, credit, inputs, transport, storage and technical assistance acts as main barriers on their working environment. The study is based on secondary data collected from Census of India, 2011. This paper reveals the gender disparity by showing the male-female work participation rate of cultivators and agricultural labourers engaged in agricultural sector in Murshidabad district. An attempt has also been taken to provide suggestive measures to uproot this discrimination.
\end{abstract}

Keywords: Agricultural labourers, agricultural sector, cultivators, gender discrimination; work participation

\section{INTRODUCTION}

Male and female participation in agricultural sector have for decades affected by gender discrimination that creates gender gap in agricultural sector. According to Giddens, A. (2009), "Gender, by contrast concerns the psychological, social and cultural differences between males and females. It means the socialization into male or a female role according to socio-cultural norms for one "s sex". Gender discrimination in Agricultural sector is a pervasive phenomenon in most countries especially the developing nations. Agricultural policymakers, in many times think 


\section{International Journal of Social Science and Economic Research}

ISSN: $2455-8834$

Volume:05, Issue:08 "August 2020"

the agricultural labourers as men and thus deny women participation in agricultural sector. Thus women are lagged behind men. It directly affects their lives. Murshidabad district is an agriculture based district. Economic level of this district is fluctuated by any aspect of these agricultural activities. There is a clear difference in working hours and daily wage paid to men and women in this district. Among the total workers of this district only $23 \%$ are women workers (District Census Handbook, Murshidabad district, 2011). However, male-female participation in agricultural sector varies from region to region in this district.

\section{LITERATURE REVIEW}

- Behera and Behera (2013) stated that despite their importance to agricultural production, women face various problems. Agricultural programmes are usually planned by men and women are lagged visibly behind men. This paper shows gender discrimination in India by focusing on the role played by women and constraints faced by them in this sector.

- Chakraborty and Chakraborty (2010) asserted that female work participation is varies inversely with female literacy and percentage of Muslim population. Women were found to be engaged in activities in these areas which are generally low-paying. This paper concludes that moderate discrimination prevails in agricultural sector in West Bengal.

- Gulistan (2014) stated that women play a vital role in Balochistan wool industry. But they cannot join in service as men do for religious factors. Women are found to work in the agricultural subsectors, but they are absent in discussion making process. It is also said that due to religious constraint, women are lagged behind men in this area. However, Balochistan Agriculture Project aims at improving the status of women in the study area.

- Kaaria et al. (2016) mentioned that gender gap determines women's participation and reduces their contributions to the agricultural sector and thereby to the achievement of broader economic and social development goals. Major strategies have been taken for strengthening women's participation in producer organizations.

- Lal and Khurana (2011) said that the amount of wages earned by the male and female labourers in the same work vary in different places. Women have lower education level too. As a result, they have the tendency to remain in subsistence agriculture. This paper reveals the role of women in different activities and average wage earning per day by them in India. Suggestive measures are also given to reduce gender discrimination in agricultural sector and thereby developing their social condition.

- Mtsor and Idisi (2014) said that in Nigeria, women are contributor of 60-80\% labourers 


\section{International Journal of Social Science and Economic Research}

ISSN: $2455-8834$

Volume:05, Issue:08 "August 2020"

in agricultural food production. But many factors like lack of credit facilities, land ownership, educational status, technical ownership etc. are the main constraints to women in agricultural sector. This paper aims to discover how gender inequality can diminish women involvement in agricultural development in Nigeria.

- Salunke (2014) asserted that globalization has widened the agricultural market but it failed to eradicate the gap between male and female work participation. Modern technology has taken the place of women in agricultural sector. Women have no job there. Women have no space for standing from the agricultural field to agricultural market as it dominated by male workers.

- Twyman et al. (2015) stated that women's participation in agricultural activities is underestimated in the fact that they are considered as the family labour and they have also domestic responsibilities. Even it is also thought that women are unskilled about production activities. Primary survey has been done to know the contribution of women in agricultural production and barriers faced by them in this sector.

\section{PROBLEM STATEMENT}

For decades, gender discrimination is an important problem prevails in agricultural sector. A woman's work has no time limit. They undertake the domestic chores and the chief economic provider of their family. Rural women performs numerous labor intensive jobs such as sowing, weeding, hoeing, grass cutting, picking, separation of seeds from fiber etc. Women are also expected to collect wood from fields. Women are forced to accept work in agriculture in their own village under any condition because they cannot migrate as easily as men. They are counted as unskilled labour and paid fewer amounts of wages too. They practiced cattle rearing and poultry farming too, but at that time also, due to poverty and down economic condition, they suffer from malnutrition.

\section{OBJECTIVES}

The main objectives of this study are:

- To find out the role of women work participation in agricultural and allied activities in Murshidabad district, West Bengal.

- To know about the impact of gender discrimination on agricultural working environment of this area.

- To find out the main obstacles of women work participation in agricultural sector of this area.

- To suggest various ways to reduce the gender gap and thereby the improvement of 
women ${ }^{e e}$ role in agricultural sector.

\section{DATABASE AND METHODOLOGY}

This paper is purely based on secondary data. To fulfill the study, descriptive data and statistical data has been used which has been collected from different web journals, online journals, published reports, e-books as well. Cartographic representation of data has been done with the help of QGIS software.

\section{STUDY AREA}

Murshidabad district lies between $23^{\circ} 43^{\prime} 30^{\prime \prime}$ North to $24^{\circ} 50^{\prime} 20^{\prime \prime}$ North latitude and $87^{\circ} 49^{\prime} 17^{\prime \prime}$ East to $88^{\circ} 44^{\prime} 00^{\prime \prime}$ East longitude. It is bounded by Bangladesh in the East, Jharkhand and Birbhum district in West, Malda district in North and Barddhaman and Nadia district in South. The total area of this district is 5316.11 square kilometers and it is the part of lower Ganges river basin. The district is divided into 5 subdivisions namely Sadar, Jangipur, Domkal, Kandi and Lalbag Subdivisions. It has 26 C.D. Blocks, 2166 villages, 7 statutory towns and 65 census towns (District Census Handbook: Murshidabad District; 2011). Bhagirathi River, distributaries of Ganges divides the district into two parts; western part is called "Rarh" region and eastern part of this river is called "Bagri" region (Comprehensive District Agriculture Plan, Murshidabad District, 2011-2012).

\section{LOCATION MAP}

\section{INDIA}

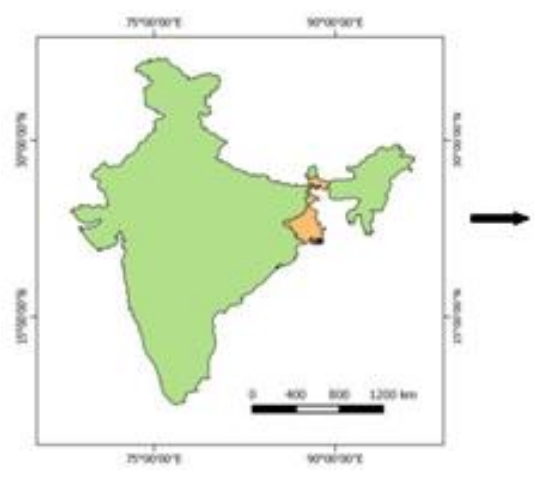

Fig.: 1
WEST BENGAL

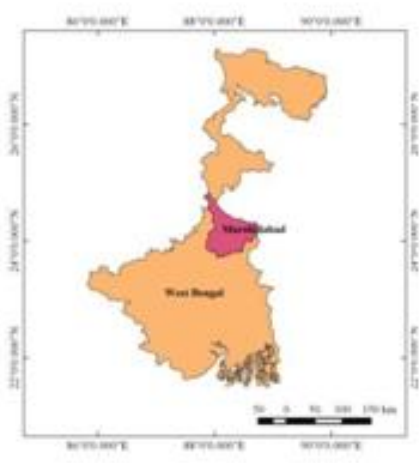

Fig $: 2$
MURSHIDABAD DISTRICT

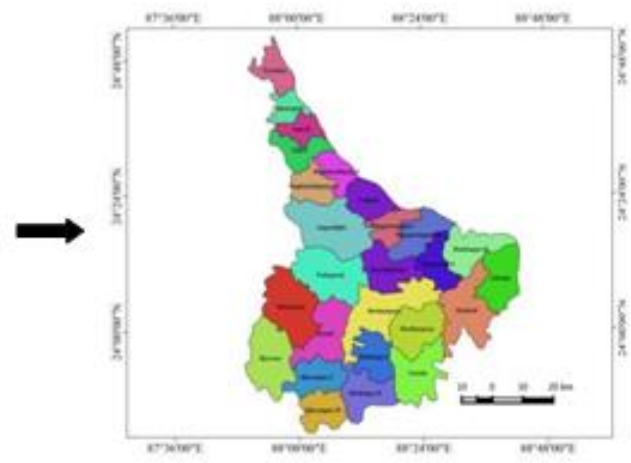

Fig.: 3

Source: An Atlas of India (2010). Oxford University Press. 
International Journal of Social Science and Economic Research

ISSN: $2455-8834$

Volume:05, Issue:08 "August 2020"

\section{RESULTS AND DISCUSSION}

Agricultural Land Use of Murshidabad District: Murshidabad district was emarked as the „Major Agricultural Districte since pre independence. The economy of this district is primarily related to agriculture. The agriculture of this district depends on alluvial soil (Pal and Let, 2012). For this reason, Murshidabad district is called "crop museum".

Table-1: Agricultural Land Use of Murshidabad District:

\begin{tabular}{|l|l|l|}
\hline Agricultural Land Use & Area (,000 hectares) & \multirow{2}{*}{ Cropping Intensity (\%) } \\
\hline Net sown area & 398.7 & \multirow{2}{*}{245} \\
\cline { 1 - 2 } Area sown more than once & 577.5 & \\
\cline { 1 - 2 } Gross cropped area & 976.2 &
\end{tabular}

Source: Agricultural Contingency Plan for District: Murshidabad; West Bengal; 2007-2008.

Role of Women in agriculture and allied activities: A large portion of women population of Murshidabad district is involved in agriculture. They play a major role in this sector along with their household chores. Rural women perform numerous labour intensive agricultural activities such as sowing, weeding, irrigation, hoeing, fertilizer application, plant protection, harvesting and storing of crops. They have to do the household chores like cooking, child rearing, water collection, fuel wood gathering, household maintenance etc. They are also engaged in livestock and poultry farming and many associated activities like milking, milk processing, and preparation of ghee are also carried out by the women.

Male-female wage difference: Male and female workers are engaged in the same field for the same time but wage got by them varies. Women are granted as unskilled labourers than male labourers. Women are forced to accept work in agriculture in their own village under very bad conditions because they cannot migrate as easily as men. The dependence of women "s labour on family farms, especially during the peak periods of sowing and harvesting has become very common. Farmers, on the other hand, also seem to prefer women as agricultural workers because they save money by using lower-paid women workers. Similarly, the work of women within family-based agriculture is preferred because it is cheaper than men labour (Behera and Behera, 2013). Women agricultural workers, although represent a big proportion of all workers, continue to receive lower wages than men. Main causes of this disparity are women"s absence in decission making process, unconscious about their legal right, religious obstacles, dropout and illiteracy etc.

Engagement of male and female population in agricultural sector, Murshidabad District, 2011: The development of a particular region is dependent upon the working population 
including both male and female population of that region. According to Census of India- 2011, in Murshidabad district, the percentage of male and female cultivators engaged in agriculture is 87.9 per cent and 12.1 per cent respectively. Same way, the percentage of male and female agricultural labourers engaged in agriculture in this area is 73.15 per cent and 26.85 per cent respectively.

Table-2: Engagement of male and female population in agricultural sector, Murshidabad District, 2011:

\begin{tabular}{|l|l|l|}
\hline & Cultivators & Agricultural Labourers \\
\hline Total & 5116688 & 10188842 \\
\hline Male & 4500041 & 7452814 \\
\hline Female & 616647 & 2736028 \\
\hline
\end{tabular}

Source: District Census Handbook, Murshidabad District, 2011.

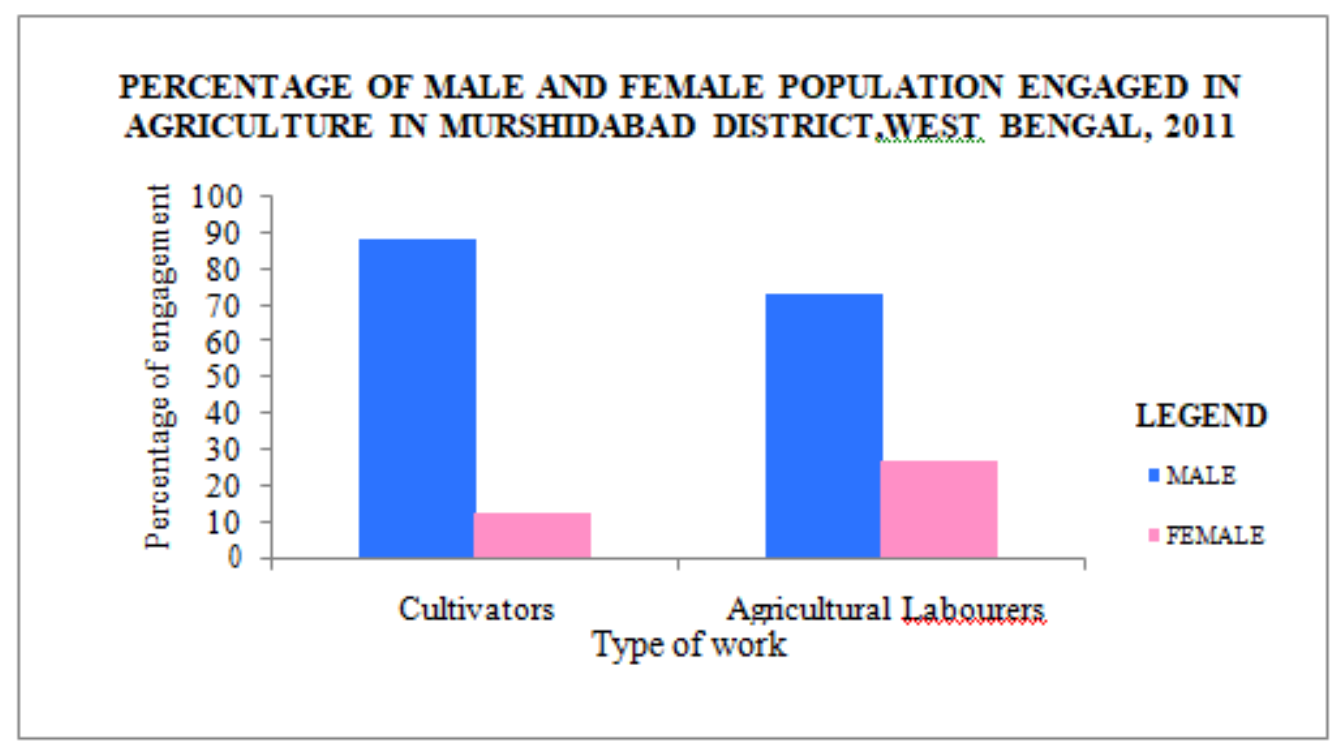

Fig.:4

In this bar graph, male-female engagement in agriculture of Murshidabad is clearly visible. In comparison to male agricultural workers, female agricultural workers are much more less. Women's unwillingness and religious factors probably acts as main barrier in this activity.

Male and Female Population Distribution of Cultivators in Agricultural Sector, Murshidabad District, 2011:

Cultivators are those people who engaged in agriculture and allied activities for 180 days or 


\section{International Journal of Social Science and Economic Research}

ISSN: 2455-8834

Volume:05, Issue:08 "August 2020"

more. Cultivators are categorized into two groups, main workers and marginal workers. Farmers who engaged in this sector for six months or more are called main workers and who engaged for less than six months are called marginal workers. Male and female work participation of main and marginal cultivators of Murshidabad district has been given in this table below:

\section{Table -3: Male and Female Population Distribution of Cultivators in Agricultural Sector, Murshidabad District, 2011:}

\begin{tabular}{|c|c|c|c|c|c|c|}
\hline \multirow{3}{*}{ C.D. Blocks } & \multicolumn{6}{|c|}{ Cultivators } \\
\hline & \multicolumn{3}{|c|}{ Main Workers } & \multicolumn{3}{|c|}{ Marginal Workers } \\
\hline & Total & Male & Female & Total & Male & Female \\
\hline Farakka & 4363 & 4103 & 260 & 719 & 551 & 168 \\
\hline Samserganj & 2841 & 2730 & 111 & 356 & 274 & 82 \\
\hline Suti-1 & 4973 & 4875 & 98 & 567 & 423 & 144 \\
\hline Suti-ll & 4059 & 3927 & 132 & 328 & 279 & 49 \\
\hline Raghunathganj-1 & 5428 & 5227 & 201 & 570 & 349 & 221 \\
\hline Raghunathganj-1l & 4277 & 4172 & 105 & 264 & 216 & 48 \\
\hline Lalgola & 9144 & 8678 & 466 & 1602 & 1115 & 487 \\
\hline Sagardighi & 16103 & 15364 & 739 & 2005 & 1277 & 728 \\
\hline Bhagwangola-1 & 7699 & 7493 & 206 & 677 & 482 & 195 \\
\hline Bhagwangola-ll & 7351 & 7195 & 156 & 457 & 229 & 228 \\
\hline Raninagar-ll & 16283 & 15913 & 370 & 1029 & 780 & 249 \\
\hline Jalangi & 17329 & 16914 & 415 & 1497 & 1108 & 389 \\
\hline Domkal & 26870 & 26205 & 665 & 2145 & 1338 & 807 \\
\hline Raninagar-1 & 11311 & 11121 & 190 & 857 & 698 & 159 \\
\hline Murshidabad-Jiaganj & 14497 & 13906 & 591 & 953 & 613 & 340 \\
\hline Nabagram & 16998 & 16048 & 650 & 1720 & 1339 & 381 \\
\hline Khargram & 16105 & 15663 & 442 & 2522 & 2009 & 513 \\
\hline Kandi & 21391 & 20737 & 654 & 2086 & 1687 & 399 \\
\hline Berhumpore & 23959 & 23376 & 583 & 2301 & 1757 & 544 \\
\hline Hariharpara & 22077 & 21622 & 455 & 2468 & 2058 & 410 \\
\hline Nowda & 17694 & 17442 & 252 & 944 & 862 & 132 \\
\hline Beldanga-1 & 15908 & 15348 & 560 & 1225 & 903 & 322 \\
\hline Beldanga-11 & 17102 & 16859 & 243 & 1235 & 1084 & 151 \\
\hline Bharatpur-ll & 8867 & 8647 & 220 & 981 & 880 & 101 \\
\hline Bharatpur-1 & 12336 & 12077 & 259 & 864 & 672 & 192 \\
\hline Burwan & 17575 & 17240 & 335 & 3669 & 3307 & 362 \\
\hline Total & 342540 & $\begin{array}{c}33288 \\
2\end{array}$ & 9358 & 34041 & 26290 & 7801 \\
\hline
\end{tabular}

Source: District Census Handbook, Murshidabad District (2011). 
From this table it has been found that $95.37 \%$ are men and $4.63 \%$ are women cultivators in Murshidabad district. In the form of cultivators, $97 \%$ are male main workers and only $3 \%$ are female main workers which is much more less. But in the form of marginal workers, $77 \%$ are occupied by men and $23 \%$ are occupied by women farmers. That is why men are all in all in agricultural sector in this district.

\section{MALE AND FEMALE POPULATION DISTRIBUTION OF CULTIVATORS IN MURSHIDABAD DISTRICT, 2011 (MAIN AND MARGINALWORKERS)}

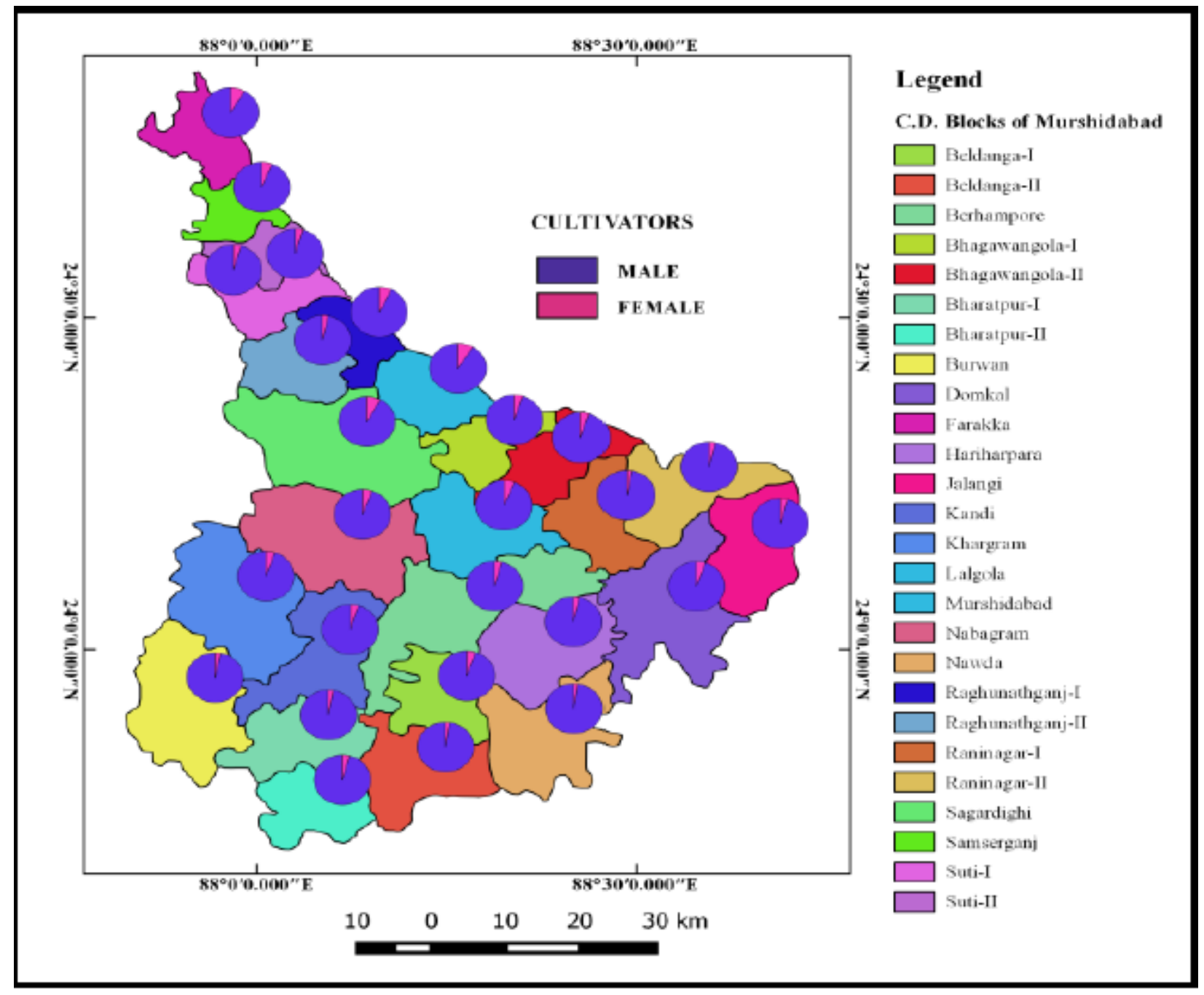

By this map it is clear that women participation in agricultural sector as cultivators is much more less in each and every C.D. Blocks of the study area. A clear gap between male-female engagement in this particular sector is found here. 


\section{International Journal of Social Science and Economic Research}

ISSN: 2455-8834

Volume:05, Issue:08 "August 2020"

\section{Male and Female Population Distribution of Agricultural Labourers in Murshidabad District, 2011:}

Agricultural labourers are those people who are engaged as labourers in the field of another person and only wages are given to them. They do not have their own land to cultivate. Male and female population distribution of agricultural labourers of this district is given below:

\section{Table -4: Male and Female Population Distribution of Agricultural Labourers in Murshidabad District, 2011:}

\begin{tabular}{|c|c|c|c|c|c|c|}
\hline \multirow{3}{*}{ C.D. Blocks } & \multicolumn{6}{|c|}{ Agricultural Labourers } \\
\hline & \multicolumn{3}{|c|}{ Main Workers } & \multicolumn{3}{|c|}{ Marginal Workers } \\
\hline & Total & Male & Female & Total & Male & Female \\
\hline Farakka & 9743 & 9241 & 502 & 5121 & 4213 & 908 \\
\hline Samserganj & 9859 & 9589 & 270 & 2350 & 2127 & 223 \\
\hline Suti-1 & 15935 & 15473 & 462 & 4333 & 3890 & 443 \\
\hline Suti-1l & 12345 & 12066 & 279 & 3732 & 3501 & 231 \\
\hline Raghunathganj-1 & 10275 & 9520 & 755 & 3968 & 2746 & 1222 \\
\hline Raghunathganj-1l & 6611 & 6488 & 123 & 1827 & 1685 & 142 \\
\hline Lalgola & 22684 & 21795 & 889 & 9884 & 9002 & 882 \\
\hline Sagardighi & 39235 & 34619 & 4616 & 16178 & 9777 & 6401 \\
\hline Bhagwangola-1 & 19477 & 18996 & 481 & 6509 & 5626 & 883 \\
\hline Bhagwangola-ll & 22667 & 22201 & 466 & 5589 & 4853 & 736 \\
\hline Raninagar-11 & 24764 & 23689 & 1015 & 7880 & 6662 & 1218 \\
\hline Jalangi & 34558 & 33238 & 1320 & 7873 & 6754 & 1119 \\
\hline Domkal & 41880 & 40845 & 1035 & 12210 & 10714 & 1496 \\
\hline Raninagar-1 & 23359 & 22270 & 639 & 7167 & 6527 & 640 \\
\hline Murshidabad-Jiaganj & 29172 & 26242 & 2930 & 7657 & 5647 & 2010 \\
\hline Nabagram & 32122 & 28502 & 3620 & 10426 & 7941 & 2485 \\
\hline Khargram & 33140 & 31980 & 1160 & 15209 & 12997 & 1212 \\
\hline Kandi & 20624 & 19241 & 1383 & 9172 & 7876 & 1296 \\
\hline Berhumpore & 41394 & 38433 & 2961 & 12820 & 11023 & 1797 \\
\hline Hariharpara & 28098 & 27317 & 781 & 11302 & 10403 & 899 \\
\hline Nowda & 28657 & 28204 & 453 & 8263 & 7915 & 348 \\
\hline Beldanga-l & 26110 & 25417 & 693 & 6306 & 5800 & 506 \\
\hline Beldanga-1l & 22466 & 21863 & 603 & 6905 & 6236 & 669 \\
\hline Bharatpur-ll & 19306 & 18801 & 505 & 6092 & 5138 & 954 \\
\hline Bharatpur-1 & 21573 & 21081 & 492 & 5447 & 4640 & 807 \\
\hline Burwan & 26278 & 25495 & 792 & 16828 & 15060 & 1768 \\
\hline Total & 622322 & 592606 & 29225 & 211048 & 178753 & 31295 \\
\hline
\end{tabular}

Source: District Census Handbook, Murshidabad District (2011). 
From the following table it is clear that $92.56 \%$ are male agricultural labourers and only $7.44 \%$ are female agricultural labourers in Murshidabad district. Men farmers determine the whole process as they have occupied $95 \%$ in main workers and women occupied only $5 \%$ in this district. In the same way $85 \%$ occupied by men marginal workers and $15 \%$ occupied by women workers.

\section{MALE AND FEMALE POPULATION DISTRIBUTION OF AGRICULTURAL LABOURERS IN MURSHIDABAD DISTRICT, 2011 (MAIN AND MARGINAL WORKERS)}

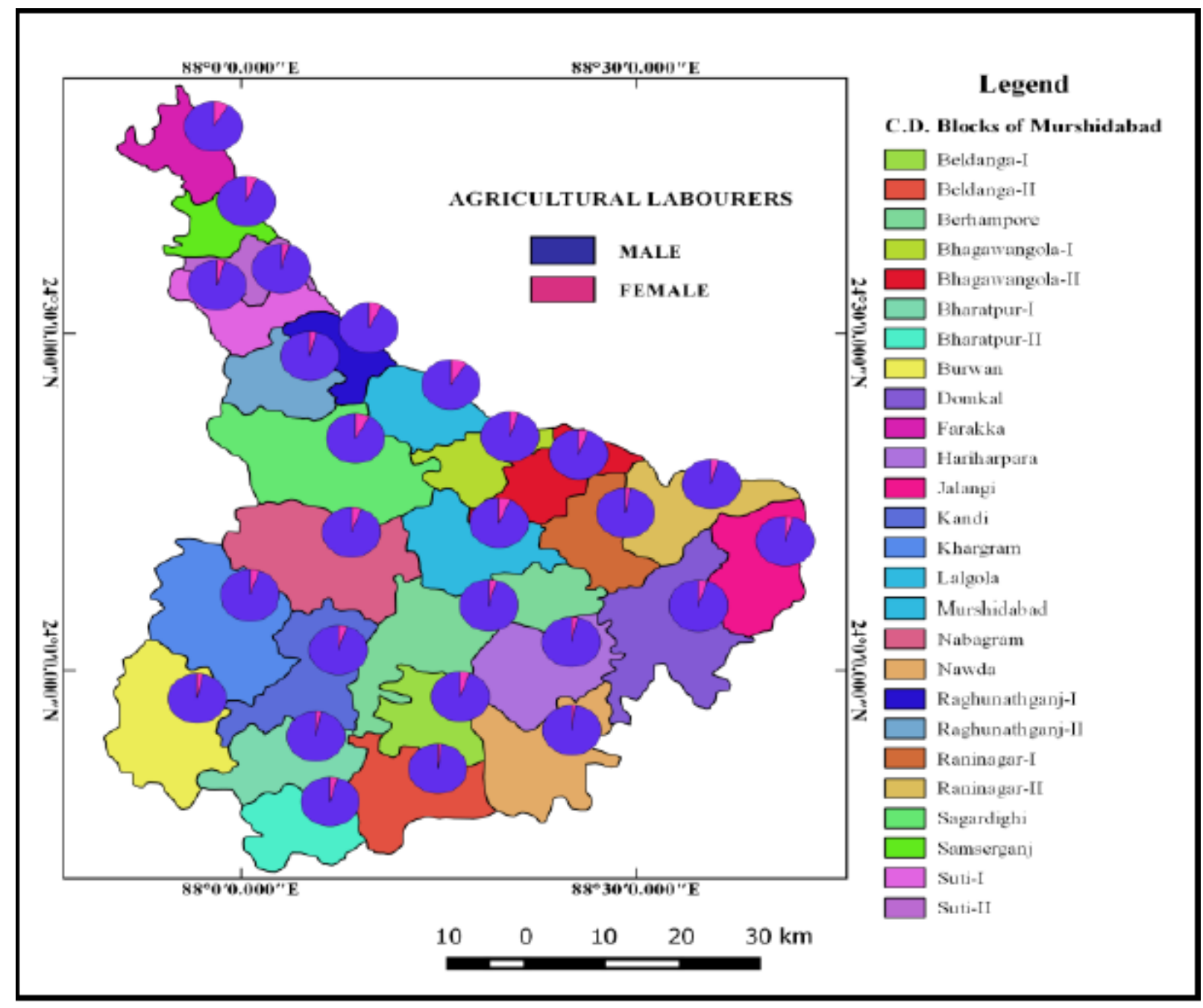

Here we can see that in the form of both main and marginal workers, men agricultural labourers plays significant role. Very few women are engaged in these sectors in each C.D. Blocks of 


\section{International Journal of Social Science and Economic Research}

ISSN: $2455-8834$

Volume:05, Issue:08 "August 2020"

Murshidabad district.

SUGGESTIVE MEASURES: Necessary steps should be taken to remove this type of problem, such as:

- More facilities should be provided to poor rural women for land, seed, agricultural and livestock extension services.

- Priority must be given to women in accessing credit on soft terms from banks and from other non- government organizations for setting up their business.

- Measures should be taken to enhance women's literacy rate.

- Women must be involved in decision-making process to introduce developmental changes.

- Women must be aware regarding their existing rights.

- Government should provide necessary aids and skill development training to women agricultural workers.

\section{CONCLUSION}

In summary, we can observe that women in this district often face many constraints in the field of agricultural activities. As mentioned above, women engagement in agricultural sector, population distribution of female workers as both cultivators and agricultural labourers in the form of main and marginal type are too less. Women are the major contributors in agriculture and its allied fields. Their work ranges from crop production, livestock production to cottage industry. Finally it can be said that the rural women are treated as sub- servant or personal property. In this regard government should encourage and enhance their skills and their work and thereby making them economically independent.

\section{REFERENCES}

- Agricultural Contigency Plan for District: Murshidabad; West Bengal, National Innovations in Climate Resilient Agriculture. Department of Agriculture Cooperation and Farmers welfare 2007-2008.

- An Atlas of India (2010). Oxford University Press, New Delhi.

- Behera, B.S. and Behera, A.C. (2013). Gender Issues: The Role of Women in Agriculture Sector in India. International Journal of Marketing, Financial Services \& Management Research, 2 (9), 134-145.

- Chakraborty, I. and Chakraborty, A. (2010). Female Work Participation and Gender Differential in Earning in West Bengal, India. Journal of Quantitative Economics, 8 (2), 


\section{International Journal of Social Science and Economic Research}

ISSN: $2455-8834$

Volume:05, Issue:08 "August 2020"

98-114.

- Comprehensive District Agriculture Plan, 2010-2011, Ditectorate of Agriculture, Murshidabad district, Government of West Bengal.

- District Census Handbook, Murshidabad District (2011). Village and Town Wise Primary Census Abstract, Directorate of Census Operations, West Bengal.

- Giddens, A. (2009). Anthony Giddens Sociology. Polity press, Cambridge, UK.

- Gulistan, A. (2014).Gender Issues in Agricultural Extension (A Case Study of Wool in Baluchistan). International Journal of Agricultural Extension, 39-42.

- Kaaria, S., Osorio, M., Wagner, S. and Gallina, A. (2016). Rural women "e participation in producer organizations: An analysis of the barriers that women face and strategies to foster equitable and effective participation. Journal of Gender, Agriculture and Food Security, 1(2), 148-167.

- Lal, R. and Khurana, A. (2011). Gender issues: The role of women in agriculture sector, ZENITH

- International Journal of Business Economics \& Management Research, 1(1), 29-39.

- Mtsor, Y.G. and Idisi, P.D. (2014). Gender inequality and women participation in agricultural development in Nigeria. Merit Research Journal of Education and Review, 2(11), 296-301.

- Pal, S. and Let, S. (2012). Flood Intensity and Potential Flood Loss Estimation in Dwarka River Basin in Eastern India; in International Journal of Geology, Earth and Environmental Sciences. International Journal of Geology, Earth and Environmental Sciences, 2 (1), 116-122.

- Salunke, S.B. (2014). Globalization and Gender Inequality- An Agricultural Perspective. IOSR Journal of Humanities And Social Science (IOSR-JHSS), 19 (3), 08-13.

- Twyman, J., Muriel, J., and García, M. A. (2015). Identifying women farmers: Informal gender norms as institutional barriers to recognizing women ${ }^{\text {ee }} \mathrm{s}$ contributions to agriculture. Journal of Gender, Agriculture and Food Security, 1(2), 1-17. 